Para enlazar con este artículo / To link to this article:

https://doi.org/10.6035/MonTI.2020.12.07

Para citar este artículo / To cite this article:

Oncins, Estella; Rocío Bernabé; Mario Montagud \& Verónica Arnáiz Uzquiza. (2020) "Accessible scenic arts and Virtual Reality: A pilot study with aged people about user preferences when reading subtitles in immersive environments." In: Richart-Marset, Mabel \& Francesca Calamita (eds.) 2020. Traducción y Accesibilidad en los medios de comunicación: de la teoría a la práctica / Translation and Media Accessibility: from Theory to Practice. MonTI 12, pp. 214-241.

\title{
ACCESSIBLE SCENIC ARTS AND VIRTUAL REALITY: A PILOT STUDY WITH AGED PEOPLE ABOUT USER PREFERENCES WHEN READING SUBTITLES IN IMMERSIVE ENVIRONMENTS ${ }^{1}$
}

\author{
ESTELLA ONCINS \\ estella.oncins@uab.cat \\ TransMedia Catalonia, Universitat Autònoma de Barcelona \\ ROCÍO BERNABÉ \\ rocio.bernabe@sdi-muenchen.de \\ University of Applied Languages, SDI München \\ MARIO MONTAGUD \\ mario.montagud@i2cat.net \\ i2cat \\ VERÓNICA ARNÁIZ UZQUIZA \\ vey.arnaiz@gmail.com \\ Universidad de Valladolid
}

1. Acknowledgements: Authors would like to thank ImAc partners for their technical contributions in preparing the end-to-end platform, from production to consumption of immersive and accessibility contents. With special thanks to Isaac Fraile for the content and all users for participating in this research. This work has been funded by European Union's Horizon 2020 program, under agreement no 761974 (ImAc project). Dr. Estella Oncins is member of TransMedia Catalonia, an SGR research group funded by "Secretaria d'Universitats i Recerca del Departament d'Empresa i Coneixement de la Generalitat de Catalunya" (2017SGR113). 


\title{
Resumen
}

El auge de los desarrollos tecnológicos en realidad virtual y otras formas de contenido inmersivo, como el video $360^{\circ}$, se ha convertido en un reto para el concepto de liveness en las artes escénicas, y resulta necesaria una revisión en los estudios de traducción audiovisual. La inclusión de estudios de recepción de subtítulos en este nuevo medio basado en realidad virtual es necesario. En el campo específico de los estudios de accesibilidad en los medios de comunicación, la accesibilidad en los medios inmersivos se encuentra aún en un estado embrionario. Este artículo explora las preferencias de dos opciones de subtítulos: subtítulos para sordos y discapacitados auditivos y subtítulos en lectura fácil, elaborados para un vídeo en $360^{\circ}$ de la ópera Roméo et Juliette, interpretada en el Gran Teatre del Liceu durante la temporada 2017/2018. El estudio se preparó y se realizó con personas de entre 50 y 79 años de edad, con el objetivo de determinar las opciones de subtitulación preferidas por las personas mayores.

Palabra clave: Realidad Virtual; Accesibilidad a los Medios; Personas mayores; Subtítulos para sordos y discapacitados auditivos; Lectura Fácil.

\begin{abstract}
The technological advancements in virtual reality and other forms of immersive content such as $360^{\circ}$ video are triggering the concept of liveness in the scenic arts, and deserve in-depth consideration in audiovisual translation studies. The reception of subtitles in this new VR-based media needs to be studied. In the specific field of media accessibility, accessibility in immersive media much research needs to be done. This article explores the preferences of two subtitle options: Subtitles for the D/deaf and hard-of-hearing and Easy-to-Read in a $360^{\circ}$ video of Roméo and Juliette the opera, played at the Gran Teatre del Liceu during the 2017/2018 season. A pilot study was prepared and conducted with the aim of determining which subtitling options are preferred by users aged between 50 and 79 .
\end{abstract}

Keywords: Virtual reality; Media Accessibility; Aged; Subtitles for Deaf/deaf and Hard-of-Hearing; Easy-to-read.

\section{Introduction}

In the turn of the century, research studies focused on the scenic arts are gaining attention in the audiovisual translation (AVT) field, which is a discipline that in its origins began with descriptive studies mainly focused on the dubbing and subtitling practices of pre-recorded AV content (Chaume 2018). 
According to Oncins (2014: 17) "in the last decade, surtitling for the stage has gained interest among academics and professionals from the AVT field and more recently in media accessibility (MA)". Still, as it will be outlined in section 2, most studies remain descriptive, based on current practices and technological constraints and subsequently lagging behind the experimental research trends in the AVT field. While reception studies for pre-recorded AV products have been emerging in recent decades (Chaume 2018), audience reception studies in the specific field of AVT for the scenic arts are still scarce (Oncins 2015, Secara 2018).

As will be explained in section 3, the average age of audiences in the scenic arts is increasing, which is a tendency in line with the aging population worldwide. According to statistics produced by the $\mathrm{UN}^{2}$ (2015a:1), the number of people in the world aged 60 and over is predicted to grow by 56\% between 2015 and 2030, which is expected to further increase. Aging is closely related to disability due to age-related impairments, such as visual, hearing, physical and cognitive. This fact has a clear impact on the MA field which has been mainly focused on audiences with disabilities (Agulló et al. 2018, Greco 2016). It paves the way for further research intended for audiences that could also benefit from MA, such as the aged, non-native speakers, the illiterate, etc.

The experience of audiences attending cinema venues with subtitles differs significantly from that of audiences attending stage performances with surtitles. According to Eugeni (2006) and Mele-Scorcia (2018), one of the most important aspects to consider in cinema settings is their 'limited bidimensional space', with eye movement between images and subtitles being limited to a flat-screen, and action in the scenes determined by the director's style. In stage performances, however, the scenic space happens to be three dimensional, as the action takes place on a more irregular basis and in different layers. Therefore, it is more difficult to focus on the most informative part of the scene and audiences will tend to focus their attention according to their interests. Within this context, a $360^{\circ}$ video recording of an opera with subtitles allows the audience to focus and move their attention towards

2. https://www.un.org/en/development/desa/population/publications/pdf/ageing/ WPA2015_Highlights.pdf 
a specific action on the stage without losing access to the text. As it will be outlined in section 4 , this triggers the concept of liveness which is intrinsic to live performances in the sense that the viewer does not consider themself a mere spectator but feels present in the virtual space. Approaches for VR align with assumptions made by Auslander (2012: 19), "liveness is an interaction produced through our engagement with the object and our willingness to accept its claim". Recent research studies carried out regarding viewer experience with $360^{\circ}$ VR technology argue that it provides a better engagement experience than the conventional 2D video (Schöne et al. 2017). Thus, as various forms of scenic arts are being recorded and broadcasted on the internet, the impact on the viewers of this new VR-based media needs to be studied.

\section{Audiovisual translation in the opera}

Surtitling was first introduced in the opera in the '80s. In its origins, it faced considerable disapproval, with some critics and directors against it and audiences mostly in favour (Burton 2009: 30). Nowadays, surtitling practice in the opera genre is not only accepted but is an established accessibility service, with most opera houses utilizing an in-house surtitling department. However, in terms of understanding the text at the opera, surtitling is still mainly used to suit the needs of hearing audiences rather than catering to the needs of sensory impaired audiences.

In terms of research, some the of earliest studies provided a descriptive analysis of the surtitling process mainly based on personal experiences (Bonwit 1998; Burton 2001, 2009; Burton \& Holden 2005; Dewolfe 2001; Low 2002). Also, from a libretto translation perspective considering the translation of lyrics in the opera genre (Desblache 2007, 2017a, 2017b; Gorlée 2005; Kaindl 1997; Low 2017), from a theatrical translation perspective distinguishing between the translation of the dramatic text and the translation for the stage performance (Carlson 2006; Espasa 2000; Ezpeleta 2007; SnellHornby 2007), and from a technical and practice perspective considering how the audience receives the surtitled product (Bartoll 2004, 2008; Griesel 2005, 2009; Mateo 2001, 2002, 2007a, 2007b; Redzioch-Korkuz 2018; Vervecken 2012; Virkkunen 2004). An extended and detailed bibliography about the 
different modalities of opera translation within the AVT field is provided by Matamala \& Orero (2008).

In the last decade, two lines of research in the AVT field for the scenic arts have gained particular significance. The first is reception studies, which lacked research but are now starting to emerge in order to assess audience reception of a surtitled production and quality perception (Mele-Scorcia 2018) and audience perception of expressivity and focus of attention (Silveira $\&$ Diaz 2012). The second is studies about surtitling practice in MA which are on the increase and will be outlined in the next section. In both cases, there is a shift from the professional perspective to the audience perspective, considering both the heterogeneous nature of the audience and their needs.

\subsection{Media Accessibility in opera}

Opera surtitling has been investigated from the wider perspective of opera accessibility, with articles by Desblache $(2018,2019)$, Eardley-Weaver (2010, 2013, 2014a, 2014b), Matamala \& Orero (2007), Neves (2010), Oncins (2014, 2015), Redzioch-Korkuz (2015) or Secara (2018) addressing the problem alongside studies on audio description (AD), surtitling for the D/deaf and Hard-of-Hearing or sign language in opera. In the specific case of surtitling for the deaf and hard-of-hearing, surtitles at opera houses are mainly intended for circumventing linguistic barriers rather than providing accessibility for all (Matamala \& Orero 2007, Oncins 2015). As stated by Matamala \& Orero (2007: 274)

"The deaf and hard-of-hearing community includes people who are partially able to hear, people who hear only certain frequencies and people who cannot hear anything at all but who can feel the vibrations of the orchestra, making opera an enjoyable experience for all of them".

Hence, the need to include extralinguistic information, such as sound effects, musical elements, repeated words or phrases, language variation, and intralingual surtitles when the opera is sung in the same language, which in turn could cater for the needs of the D/deaf and Hard-of-hearing (D/d HoH) audiences (Eardley-Weaver 2014a, Matamala \& Orero 2007). In addition, most opera houses have seatback screens, allowing for features that were primarily intended for $\mathrm{D} / \mathrm{d} \mathrm{HoH}$ audiences to be integrated, such as character 
identification with colours or labels with the character name, and therefore expanding the scope of accessibility services in order to reach wider audiences. According to Romero-Fresco (2018: 189), "MA is referred to almost exclusively as it concerns persons with disabilities, thus overlooking the benefits it can bring about for the elderly, linguistic minorities or migrants".

As we have seen in this section, AVT research in the scenic arts has mainly focused on users according to their linguistic needs, whereas MA research has largely profiled users based on their specific sensory needs, mainly deaf and blind. Thus, most developed accessibility solutions only address a specific need, namely SDH for the deaf and audio description for the blind. No needs have been considered for other target groups that present different sensory needs simultaneously and could profit from the same accessibility services with adapted solutions, such as the elderly (i.e. an old person can suffer different levels of visual, hearing and cognitive decline). Therefore, the aged are also potential users and can benefit from accessibility services. Accessibility reception studies should be carried with this target group to test and validate their acceptance and preferences when using the accessibility services. This will help MA to both broaden the scope of MA studies and address the different needs of all audiences regardless of their disabilities.

\section{Audience aging and accessibility}

Recent research into audience age in the scenic arts, mainly in theatre and opera, agree on the increasing average age of the audience. According to research carried out in the UK by the Audience Agency ${ }^{3}$ in 2017, the provided data shows that audiences in the UK for classical music artforms, such as the opera, are much more likely to be in middle and older age groups: $42 \%$ are likely to be aged between $41-60$ years old and $37 \%$ aged over 61 . Just $7 \%$ are likely to be aged under 31 . Older audiences are not a phenomenon restricted to classical music artforms but are also present in other scenic artforms, such as the theatre.

3. https://www.theaudienceagency.org/asset/1303 
Population aging is a long-term trend and a challenge in many fields of contemporary societies. According to $\mathrm{UN}^{4}$ statistics (2015a:4), "by 2030, older persons are expected to account for more than 25 per cent of the populations in Europe and in Northern America, 20 per cent in Oceania, 17 per cent in Asia and in Latin America and the Caribbean, and 6 per cent in Africa". This aging tendency is highly relevant when observing disability rates among older persons. The UNCRD ${ }^{5}$ provides a framework for action in a number of articles highlighting the correlation between aging and disability, one of them being article 9 (accessibility).

With the advent of the information society, new research and technological developments are increasing in the field of information and communication technologies (ICT), and accessibility services can be improved and personalized depending on user needs. As will be outlined in the following section, while aging is closely related to the development of disabilities and the use of new technologies such as VR is widespread, mainly for therapeutic purposes, there is still a gap in providing accessibility services tailored to the needs of seniors for enjoying new forms of cultural related content.

\subsection{Digital technology and accessibility}

Contemporary societies are also characterised by widespread use of technology in all spheres of life. As we will see in section 4, all participants taking part in this pilot study aged 50-79 years owned and used two main ICT products on a daily basis, namely a TV and a smartphone. In addition, three participants reported to own and use a tablet, three participants owned and used a PC and three participants owned and used a notebook, all of them on a daily basis.

In this context, the World Wide Web Consortium (W3C) is a leading, internationally recognised organization which works on providing guidelines to ensure the long-term growth of the web. One of its main design principles is to provide a Web for all through the W3C Web Accessibility Initiative (WAI), which develops standards and support materials to help users to understand and implement accessibility. In their literature review conducted in 2008,

4. https://www.un.org/en/development/desa/population/publications/pdf/ageing/ WPA2015_Highlights.pdf

5. https://www.un.org/development/desa/disabilities/disability-and-ageing.html 
'Overview of web accessibility for older users', they state that aging is not only related to hearing loss but also visual, physical and cognitive decline. According to the statistics provided, hearing loss is experienced by $47 \%$ of people of 61 to 80 years old and $93 \%$ of people over 81 years old. Moderate or severe hearing loss or profound deafness is experienced by $20 \%$ of people aged $61-80$ and $75 \%$ of people over 80 . Furthermore, it states that the impact of hearing loss makes distinguishing between audio elements difficult as the background and higher pitch sounds can be missed.

In relation to visual decline, the prevalence is $16 \%$ of people aged between $65-74,10 \%$ aged $75-84$ and $46 \%$ of people aged $85+$. Impact of visual decline mainly affects the ability to focus, contrast sensitivity and the perception of change of color. In the case of physical decline, the numbers rise to $50 \%$ for people over 65 years old due to arthritis and 20\% due to tremors. Only 4\% of people aged 65 are affected by Parkinson's. The impact is mainly on motor skills. In the case of cognitive decline, around $20 \%$ of people aged 70 years are estimated to suffer mild cognitive impairment (MCI). The impact can mainly be found in short-term memory and concentration and distraction issues.

In most cases, aging is not only related to one of the aforementioned disabilities but individuals experience several simultaneously. For the purpose of this study, the focus will be placed on hearing loss and cognitive decline. Therefore, two types of subtitling have been elaborated upon: Subtitles for Deaf and Hard-of-Hearing (SDH) to approach the hearing loss and Easy to Read (E2R) subtitles to approach the cognitive decline.

\subsection{VR and elderly}

Although virtual reality (VR) technology has been implemented as a tool to address the health issues of older adults, its applicability to social integration is underrepresented in literature, and less is known about its efficacy in this area in terms of its contribution to overall wellness and well being in later life. Expanding the possibilities of VR beyond traditional entertainment purposes holds considerable potential for the senior range group.

6. https://www.w3.org/WAI/older-users/\#background 
Since technology usage largely depends on attitude, and with older adults tending to more negative attitudes towards new technology, it is important to understand attitudes towards wearable head-mounted display (HMD) devices to enjoy virtual reality audiovisual content in this target group. This rising popularity is likely to be facilitated by the availability of affordable HMD that deliver high-quality immersive experiences. As many health problems are more prevalent in older adults, who have less experience with technology, it is important to know whether they are willing to use immersive virtual reality. In this pilot study, we assessed the initial attitude towards head-mounted, immersive virtual reality in 8 older adults, aged 50 to 79 years. While none of the participants had a device to access VR content and with 7 out of 8 participants never having enjoyed VR content, three users reported to be very interested in VR content such as $360^{\circ}$ video, three participants were interested and two participants were neutral. As a result, it could be asserted that despite the age range, all participants showed a positive and a willing attitude towards the VR content. In all cases, attitudes towards immersive virtual reality changed from neutral to positive after a first acclimation, video exposure to immersive virtual reality with an Oculus go HMD. Therefore, the inclusion of senior people in MA reception studies could prove to be beneficial not only to grant access to content to this target group but also to enlarge the concept of accessibility. In the field of MA, an approach that includes accessibility, usability, and inclusion is needed to grant access to audiovisual content to all audiences.

\section{Testing SDH and E2R formats in immersive environments}

The test was carried in order to analyse how different accessibility solutions, namely SDH and E2R subtitles, for immersive $360^{\circ}$ video content were received and perceived by senior audiences. The goal of this pilot study was to identify which is the preferred subtitled option, namely SDH or E2R, by the most representative age group in scenic art audiences: the senior audience. Similarly, the test tried to determine which of the two subtitle types studied was preferred. In order to control the entire process set-up limitations and other experiment conditions that could alter final results, the test was designed as a pilot study that could provide some preliminary information. 
The following sections will describe the details of the pilot study, from its set up and methodology to the final evaluation of the results.

\subsection{Participants}

As reported in section 3, there is an increasing age in the audience profile attending stage performances, especially in the case of the opera. Therefore, it seemed necessary to focus our pilot study on this target group. To that end, users from a particular age range, with and without recognized disabilities were included: eight participants -five female and three male- with ages ranging from 50 to 79 (standard deviation 9.01) were recruited for the test. While none of the participants used hearing aids, two out of the eight participants reported mild hearing loss since they were 60 years old. Five participants wore glasses and one participant wore contact lenses.

The AV content was in French and subtitles in both formats were displayed in Spanish. None of the participants reported to speak or understand French. All participants were Spanish. Seven participants were bilingual with Spanish and Catalan as their mother tongues, and one participant only spoke Spanish. Three participants claimed that they never use subtitles and five reported that they use them sometimes depending on the AV content and language of the content.

As stated before, aging is closely related to the development of one or more disabilities. Aged people can develop sensory and/or mobility decline. Our main aim was to analyse how aged people accept and perceive two types of subtitles, which are primarily created to cater to specific accessibility needs of a specific group. SDH are intended for Deaf and $\mathrm{HOH}$ and E2R subtitles are intended for people with cognitive disabilities. As explained before, subtitles are not only beneficial for D/deaf and $\mathrm{HoH}$ audiences, but also for the aged, language minorities and non-native speakers. This is due to the wide applicability of subtitles, as discussed in Section 1.

\subsection{Evaluation stimuli}

For the purpose of the test, a total of 4 clips, each with a duration of 4 minutes and 15 seconds, were used. The clips were extracted from a $360^{\circ}$ video recording at a general rehearsal for the opera Roméo et Juliette from Charles 
Gonoud (1867), played at the Gran Teatre del Liceu in Barcelona in season 2017/2018. This was a co-production between Gran Teatre del Liceu and the Santa Fe Opera, directed by Josep Pons. The set was located in the context of the American Civil War (1861-1865). The clips selected are different scenes from the opera, presenting different actions located on stage. The particularity of this $360^{\circ}$ video recording is the three-dimensionality of the space, the viewer can turn his/her attention to the orchestra or other parts of the theatre's interior. In this case, if the actors start singing, a blinking arrow appears after the subtitle to inform the viewer that an action is taking place on the stage. In all cases, the viewer can easily locate the speakers in the video, which are located in a two-dimensional space on the stage. This was important for the test in order to help viewers locate the action, especially for the users who were not familiar with the use of VR technology.

For the first condition - SDH subtitles, two clips from the opera were used. Surtitles from the in-house surtitiling department at Gran Teatre del Liceu were provided for the tests. SDH standards from UNE 153010: 2012 in Spain and further recommendations from Arnáiz-Uzquiza (2012) were applied in order to be compliant with the accessibility principles for Deaf and Hard-of-Hearing audiences. Therefore, colours -yellow, cyan, green, magenta, red and white- were used to identify the different characters. In the first clip, there are 6 speakers and each of them is identified by a different colour. In the second clip, there are 5 speakers and each speaker is also identified by a different colour. In addition, extra-linguistic information was made available. Exposition time of the subtitles on the screen was adapted to ensure readability. In this regard, it is important to highlight that while synchronicity is a key issue in the subtitles of pre-recorded AV content, in the specific case of operatic productions, as pointed out by several authors (Burton 2001; Desblache 2007; Dewolfe 2001; Low 2002; Virkkunen 2004) the music tempo is important. Contrary to the six-second rule (Díaz Cintas $\&$ Aline Remael, 2007) used in subtitling, surtitles at the opera may present longer exposition times. As Virkunnen (2004: 93) points out "The audience uses the surtitles for communicating with other symbolic modes used in the performance for creating meanings". As Burton \& Holden 2009:33) state, "If a text contains much repetition, the title can be left up for a long period 
if necessary, or unobtrusively repeated later". Therefore, longer exposition times are generally accepted by the audience.

For the second condition, E2R subtitles, the same opera clips were used. For the elaboration of the E2R subtitles, the SDH subtitles were modified following the recommendations of Inclusion Europe "European standards for making information easy to read and understand" (2016). The resulting E2R subtitles were validated by end-users prior to this pilot test. As a result, following the feedback provided, the lexicon was adapted and reduced, and the extralinguistic information was removed. Exposition time and colours were maintained to allow users enough time to read them and ensure better readability and understandability according to the European standards. Also, as Alba Rodríguez (2014) highlights, Easy-to-read users usually do not have a great reading speed. Regarding the use of colours to identify the speakers, the European standards allow the change of colours for speaker identification but not a change of position.

As can be seen in Fig 1 and Fig 2, in terms of presentation, in both cases the same font type and font size were used in order to avoid possible reception deviations in the results. According to the European standards on easy-toread and understand 'Information for all'7 (2016: 13), "sans fonts are harder to read because the shape of the letters is not as clear". Therefore, in the case of the font type, a Roboto in bold was selected as a sans-serif font.

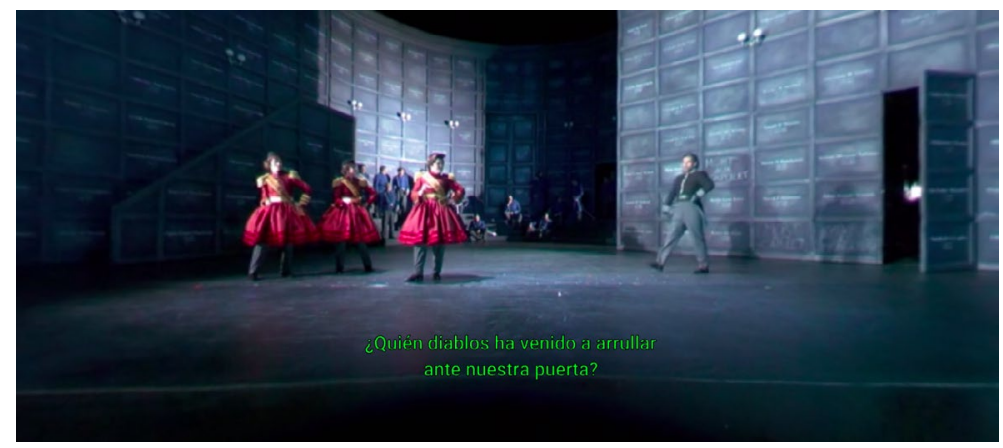

Figure 1. SDH Subtitles

7. https://easy-to-read.eu/wp-content/uploads/2014/12/EN_Information_for_all.pdf 


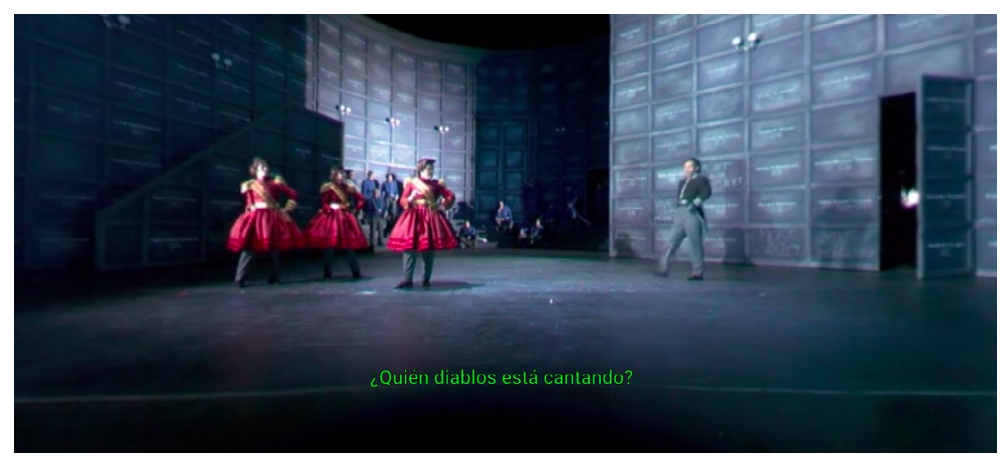

Figure 2. E2R Subtitles

As shown in Fig 3 and Fig 4, regarding the font size of the subtitles, the recommendation of the standards is to use a large font. It should be highlighted that in VR, which is a 3D environment, it is difficult to calculate the size of the font in pixels which belong to a $2 \mathrm{D}$ world. Therefore, the font size was defined according to the large size available in the ImAc player, which is calculated at 37 characters per line, to meet the Comfortable Field of View $(\mathrm{CFoV}) /$ Safe Area. In addition, following the European standards for making information easy to read, the position of the subtitles in both cases was placed at the bottom of the screen throughout the duration of the video.

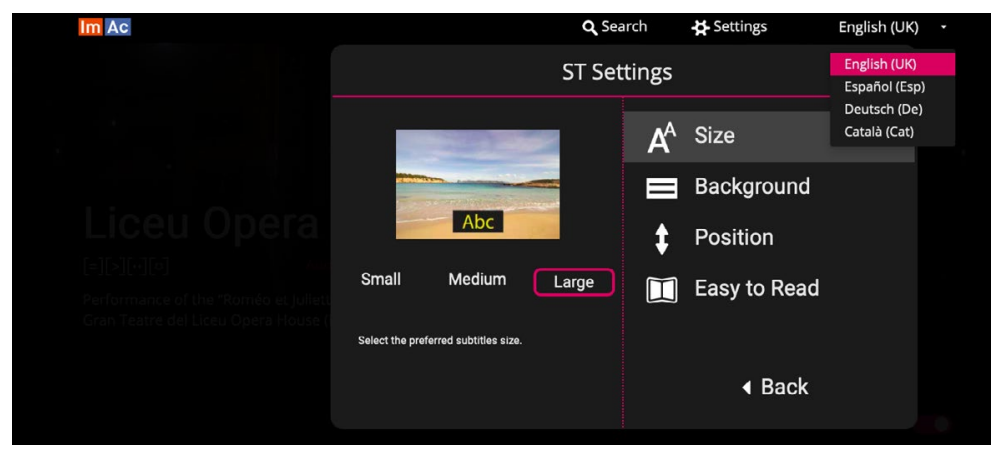

Fig 3. Imac Player settings 


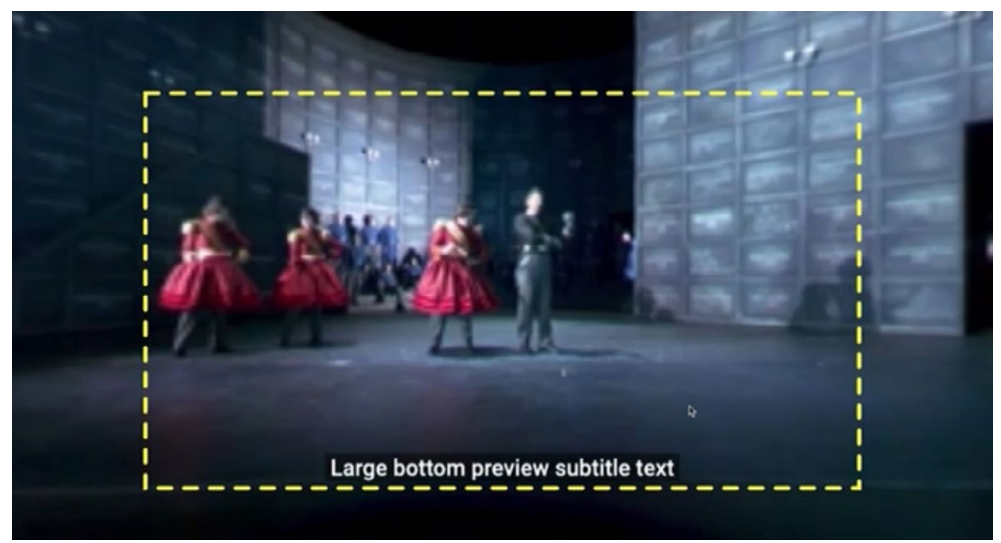

Fig 4. Large bottom preview of the subtitle text

\subsection{Evaluation Setup}

In order to conduct the evaluation, an Apache webserver was setup (no high computational resources are required) to host the player resources and the media assets $\left(360^{\circ}\right.$ video and subtitles). The player was run on a standalone VR Oculus GO (32GB) that accessed the server from a different building and access network in the same city, via a conventional $802.11 \mathrm{~b}$ WiFi network. The Oculus GO accessed the player via its WiFi connection and by typing the target URL pointing to the server resources. Note that the other types of consumption devices, and other HMDs, could have been used in the evaluations.

The $360^{\circ}$ videos were converted into Moving Picture Experts Group (MPEG) Dynamic Adaptive Streaming over HTTP (DASH), encoded in multiple qualities (with bit rates ranging from $8 \mathrm{Mbps}$ to $2 \mathrm{Mbps}$ ), and segmented in chunks with a duration of 3s. This allows an efficient, quality switching adaptation, based on the network and consumption device conditions. The subtitle files were delivered independently of the video segments, but they were signalized as part of the video metadata files. An overview of the evaluation scenario and setup can be seen in Fig 5 . 


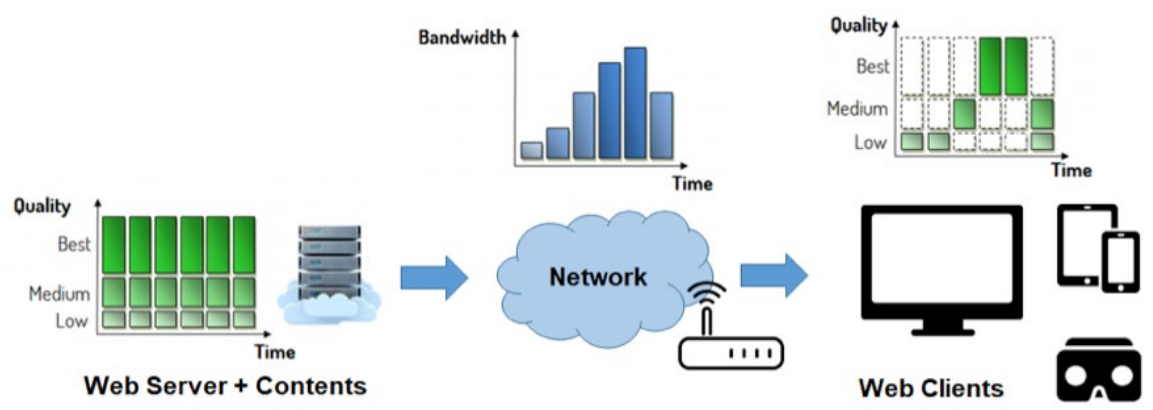

Figure 5. Overview of the evaluation scenario and setup

\section{3. Evaluation methodology}

Participants were first exposed to an acclimation clip at the beginning of the test session, so they could become comfortable with the HMD and the type of content. Except for one, all participants had no experience with HMD and VR experiences. This was later confirmed by the replies to the demographic questionnaire. After this, each participant watched two clips with a different variable, one with SDH and another with E2R subtitles. The four clips and two conditions were randomized and counterbalanced using a Latin square, to avoid the order of presentation affecting the results.

The study was conducted in one session with a single task. As part of the ImAc project this test was a replication of the pilot study carried out by Agulló et al. (2020) with different user profiles and AV content but the same accessibility service. The aim was to further assess users' preferences in a specific age group (elderly), and in a specific genre (opera), recorded in $360^{\circ}$ video. Therefore, it was essential to test two different types of subtitles that would cater for the accessibility needs of the viewer, rendering the immersive experience more accessible. An additional objective of the test was to assess if old age people could be a potential user group for the $360^{\circ}$ video recordings in the specific field of the scenic arts.

In order to gather feedback from the users a specific questionnaire for preference was created for each subtitling type (SDH and E2R). The questionnaire presented below, included closed questions to allow users 
to express their preferences between both subtitling types and to provide feedback regarding the selected or discarded option. Also, open questions in a 5-point Likert scale were added to gather feedback on their reasons in order to determine how easy it was to read and understand both subtitle types in the video.

\section{Preferences (SDH vs E2R) Questionnaire}

Please indicate all responses gathered in the open questions. Please indicate the participant code. For example:

UABI: I think the Easy to read subtitles are a better system.

1. What system do you prefer for subtitles?

\begin{tabular}{|l|l|}
\hline a) SDH & b) E2R \\
\hline & \\
\hline
\end{tabular}

2. Please, explain why you prefer the above indicated option.

3. Please explain why you did not choose the other option in question 1).

4. What do you think could be improved, and how?

5. How easy was it to read the subtitles for Deaf and Hard of Hearing?

\begin{tabular}{|l|l|l|l|l|}
\hline 1 - very difficult & 2 & 3 & 4 & 5-very easy \\
\hline & & & & \\
\hline
\end{tabular}

6. How casy was it to read the subtitles Easy to read?

\begin{tabular}{|l|l|l|l|l|}
\hline $1-$ very difficult & 2 & 3 & 4 & 5-very easy \\
\hline & & & & \\
\hline
\end{tabular}

7. How casy was it to understand subtitles for Deaf and Hard of Hearing?

\begin{tabular}{|l|l|l|l|l|}
\hline $\begin{array}{l}\text { 1- not useful at } \\
\text { all }\end{array}$ & 2 & 3 & 4 & 5-very useful \\
\hline & & & & \\
\hline
\end{tabular}

8. How easy was it to understand Easy to read subtitles?

\begin{tabular}{|l|l|l|l|l|}
\hline $\begin{array}{l}\text { 1- not useful at } \\
\text { all }\end{array}$ & 2 & 3 & 4 & 5-very useful \\
\hline & & & & \\
\hline
\end{tabular}

9. Do you think you will be able to enjoy $360^{\circ}$ videos with this type of subtitles? Explain your answer.

Figure 6. Questionnaire for the pilot tests. 
After watching the two clips, participants were asked to complete this preference questionnaire, so that they could report on their experience with both options for SDH and E2R subtitles.

\section{5. Evaluation results}

At the beginning of the session, a demographic questionnaire was used in order to gather information about the participants. Three participants had a university education, three had professional training and two had secondary education. Only one participant was familiar with VR content. Three participants were very interested in VR content, three were interested and two were neutral. None of the participants owned VR equipment. Regarding the type of AV content, animations were the least valued, six participants were not interested and two participants were interested. On the other hand, documentaries were the most valued, five participants were very interested and three participants were interested. Three participants claimed that they never use subtitles and five claimed that they use them sometimes depending on the content and language of the AV content. Regarding the reasons to use subtitles, one participant said to learn languages and four said that they used them because subtitles helped them to understand, and three said that they never use subtitles.

The results obtained regarding preferences were that five $(62,5 \%)$ out of eight participants preferred E2R subtitles. The main reasons for having chosen this option according to the participants were that they are shorter and easier to read than SDH and that with the E2R subtitles they had more freedom to look at the visual content of the scenes without missing the subtitle content. When asking, 'Why did they do not choose the other option?' the reasons were because SDH subtitles were denser, longer and more difficult to read. On the other hand, participants that chose the SDH option argued that SDH were more defined and clearer, and the language, more accurate. Regarding the question, 'What do you think could be improved, and how?', participants that favoured E2R subtitles reported that SDH subtitles should be shorter, be made easy to read, text should be reduced as much as possible and should adopt the visibility and readability of the E2R option. Conversely 
participants, that chose SDH subtitles argued that E2R subtitles should use more accurate language.

Regarding the closed questions on readability and understandability of both subtitle options: For E2R, 6 participants (75\%) reported that they were very easy to read, 1 participant $(12,5 \%)$ stated that they were easy to read and only 1 participant $(12,5 \%)$ that they were very difficult to read. For understandability of E2R subtitles, almost all participants, (87,5\%), answered that they were very useful in order to understand and only 1 participant $(12,5 \%)$ that they were not at all useful. However, results for the readability and understandability of SDH subtitles were more varied but showed the same values for both concepts, 2 participants (25\%) replied that SDH subtitles were very easy and very useful, 3 participants $(37,5 \%)$ that they were easy and useful, 2 participants (25\%) that they were difficult and not useful and only 1 participant $(12,5 \%)$ that they were very difficult and not at all useful.

When comparing the feedback provided for the question, 'Do you think you will be able to enjoy $360^{\circ}$ videos with this type of subtitles? Explain your answer', 7 participants $(87,5 \%)$ agreed on a positive answer, arguing that subtitles in E2R were easy to read and facilitated understanding the plot, that they were not as invasive as SDH subtitles and allowed for more time to be spent enjoying the stage performance, the size of the font was easy to read and the eye became easily adapted to subtitles in this format. Regarding SDH subtitles, participants who favoured this option reported that they help them to understand the plot of the performance and that subtitles are a good means of understanding the plot of the AV content. The only negative answer for this question was because the participant had a reluctance towards virtual worlds.

It should be mentioned that while SDH subtitles included non-speech information, none of the participants provided any positive or negative feedback, which can be considered as a positive outcome, meaning that non-speech information does not interfere with the viewing experience. In addition, the use of colours for character identification was favoured by all participants. This could also be considered as a positive outcome as it can be applied to both subtitle options. Hence, a wider notion of media accessibility covering the needs of the different audience profiles could be achieved. Yet, in 
order to validate these considerations, further research with a broader number of participants is required.

\section{Conclusions and future work}

Reception studies in MA are mainly focused on people with disabilities, namely Deaf/deaf, hard of hearing, blind and visually impaired. According to UN statistics, there is an aging tendency in our society, which at the same time is highly related to disability rates among older persons. The UN (2015b) ${ }^{8}$ provides a framework for action in a number of articles highlighting the interrelations between aging and disability, one of them is article 9 (accessibility). At the same time, audience profile in the scenic arts is also aging and access to AV content has to be granted. Hence, it is relevant to include the elderly in MA studies.

The purpose of this pilot study was to determine what effect SDH and E2R subtitles would have on elderly perceptions. Based on the results presented in the previous section, it can be concluded that in terms of presence there is not a big difference between SDH and E2R subtitles. The latter are favoured over the former subtitles because they allow for longer enjoyment of the visual content in the AV product. Even if the information provided is reduced and therefore exposition times are longer, E2R subtitles seem to be the most preferable among the elderly. However, further tests with a larger number of participants should be carried out in order to assess the preference for this type of subtitling, which at the same time is a new line within the Media Accessibility field (Bernabé \& Orero 2019).

The scope of this preliminary study was to test two different types of subtitles, namely SDH and E2R with a limited number of participants. A specific group profile (aged people) was identified to clarify the willingness of this target group to use these technologies and the suitability of SDH or E2R subtitles. The selected AV content might have had an impact on preferences and presence results that was not directly related to the different subtitle modes.

To conclude, from this preliminary pilot study carried out and in line with previous studies (Hughes et al. 2017, Huygelier et al. 2019, Roberts

8. https://www.un.org/development/desa/disabilities/disability-and-ageing.html 
et al. 2018) it seems that older adults are willing to use HMD-VR and have more positive attitudes towards HMD-VR after a first, positive experience in immersive AV content. According to the feedback received by some participants, future research for the use of E2R subtitles in immersive AV content for different audiovisual genres should be conducted, especially in the case of travel documentaries or cultural related AV content. This could prove to be relevant in assessing whether the type of content has a direct impact on the viewers' preferences and levels of presence.

\section{Bibliography}

AGulló, Belén; Mario Montagud \& Isaac Fraile. (2020) "Making interaction with virtual reality accessible: rendering and guiding methods for subtitles." AI EDAM (Artificial Intelligence for Engineering Design, Analysis and Manufacturing) 33:4. Electronic version: <https://ddd.uab.cat/pub/ artpub/2020/203753/AIEDAM_-_Article_Agullo_Montagud_Fraile_-_PREPRINT_VERSION.pdf>

AGulló, Belén; Pilar Orero \& Anna Matamala. (2018) "From disabilities to capabilities: testing subtitles in immersive environments with end users." Hikma 17, pp. 195-220. Electronic version: <https://www.uco.es/ucopress/ojs/index. php/hikma/article/view/11167>

AlBA RODRÍGUEZ, Teresa. (2014) "Traducción audiovisual accesible a personas con discapacidad intelectual mediante el uso de subtítulos adaptados." Estudios de Traducción 4, pp. 199-209. Electronic version: <https://revistas.ucm.es/ index.php/ESTR/article/viewFile/45376/42696>

ARNÁIZ-UZQUIZA, Verónica. (2012) "Los parámetros que identifican el Subtitulado para Sordos. Análisis y clasificación.” In: Agost Canós, Rosa; Pilar Orero \& Elena Di Giovanni (eds.) 2012. MonTI. Monografías de Traducción e Interpretación 4, pp. 103-132. Electronic version: <http://www.erevistes.uji. es/index.php/monti/article/view/1590/1334>

Audience Agency. (2017) "National Classical Music Audiences. An analysis of Audience Finder box office data for classical music events 2014-2016." Electronic version: <https://www.theaudienceagency.org/asset/1303>

Auslander, Philip. (2012) "Digital liveness. A Historico-Philosophical Perspective." PAJ: A Journal of Performance and Art 34:3, pp. 3-11. Electronic 
version: <http://raley.english.ucsb.edu/wp-content/Engl800/Auslanderdigital-liveness.pdf>

BARTOLL, Eduard. (2004) "Parameters for the classification of subtitles." In: Orero, Pilar (ed.) 2004. Topics in audiovisual translation. Amsterdam: John Benjamins, pp. 53-60.

BARTOLL, Eduard. (2008) Paràmetres per a una taxonomia de la subtitulació. Ph.D. thesis. Barcelona: Universitat Pompeu Fabra. Electronic version: <https:// www.tdx.cat/handle/10803/7572>

BERNABÉ, Rocio \& Pilar Orero. (2019) "Easy to Read as Multimode Accessibility Service." Hermeneus 21. (In press)

Bonwit, Stuart. (1998) "Mac at the opera." Washington Apple Pi Journal, May/June 1998, p. 30. <http://www.wap.org/journal/surtitles/surtitles.html>

BURTON, Jonathan. (2009) "The joy of opera. The art and craft of opera subtitling and surtitling." In: Kemble, Ian (ed.) 2009. The Changing Face of Translation. Proceedings of the 8th Portsmouth Translation Conference 2008, pp. 29-34. Electronic version: <http://www2.port.ac.uk/media/contacts-and-departments/slas/events/tr08-burton.pdf>

BURTON, Jonathan. (2001) Writing surtitles. Unpublished paper provided by the author and written for the Royal Opera House, Covent Garden, pp. 1-17.

BurTon, Jonathan \& Amanda Holden. (2005) "Oper Übersetzen", Die Horen. Zeitschrift für Literatur, Kunst und Kritik, 218: 124.

CARLSON, Marvin. (2006) Speaking in Tongues: Languages at Play in the Theatre. Michigan: University of Michigan Press.

CHAUME, Frederic. (2018) "An overview of audiovisual translation: Four methodological turns in a mature discipline." Journal of Audiovisual Translation 1, pp. 40-63. Electronic version: <https://www.jatjournal.org/index.php/jat/ article/view/43/3>

Desblache, Lucile. (2019) How is Music Translated? Mapping the Landscape of Music Translation. Music and Translation. London: Palgrave Macmillan.

DESBLACHE, Lucile. (2018) "From minor to major: Accessing marginal voices through music. New ways for translation?" In: Lewandowska-Tomaszczyk, Barbara (ed.) 2018. Contacts \& Contrasts: Languages, Translation and Educational Contexts. Cham: Springer, pp. 143-155.

Desblache, Lucile. (2017a) “Music Translation.” In: Sin Wai, Chan (ed.) 2017. An Encyclopaedia of Practical Translation and Interpreting. Hong Kong: The Chinese University Press. 
Desblache, Lucile. (2017b) "Music." In: Washbourne, Kelly \& Ben van Wyke (eds.) 2017. The Routledge Handbook of Literary Translation. London: Routledge, pp. 282-296.

DesblaCHE, Lucile. (2007) "Music to my ears, but words to my eyes?: Text, opera and their audiences." Linguistica Antverpiensia, New Series 6, pp. 155-170.

DEWOLFE, Linda. (2001) "Surtitling operas. With examples of translations from German into French and Dutch." In: Gambier, Yves \& Henrik Gottlieb (eds.) 2001. (Multi)Media translation, concepts, practices and research. Amsterdam: John Benjamins, pp. 179-188.

DíAz CinTAS, Jorge \& Aline Remael. (2007) Audiovisual Translation: Subtitling. Manchester: St. Jerome.

ESPASA, Eva. (2000) "Performability in translation: Speakability? Playability? Or just saleability?" In: Upton, Carole-Ann (ed.) 2000. Moving target. Theatre. Translation and cultural relocation. Manchester: St. Jerome, pp. 49-62.

EzPeleta, Pilar. (2007) Teatro y traducción. Aproximación interdisciplinaria desde la obra de Shakespeare. Madrid: Cátedra.

EARDLEY-WeAVER, Sarah. (2014a) "Opera (Sur)titles for the Deaf and the Hard-ofHearing.” In: Díaz Cintas, Jorge; Josélia Neves \& Diana Sanchez (eds.) 2014. Audiovisual Translation - Taking Stock. Amsterdam \& New York: Rodopi, pp. 261-277.

EARDlEy-WeAVER, Sarah. (2014b) Lifting the Curtain on Opera Translation and Accessibility: Translating Opera for Audiences with Varying Sensory Ability. Ph.D. Durham University. Electronic version: <http://etheses.dur.ac.uk/10590/> EARDley-WeAVER, Sarah. (2013) "Opening Eyes to Opera: the Process of Translation for Blind and Partially-sighted Audiences." In: EhrensbergerDow, Maureen; Birgitta Englund Dimitrova; Severine Hubscher Davidson \& Ulf Norberg (eds.) 2013. Describing Cognitive Processes in Translation: Acts and Events. Amsterdam: John Benjamins, pp. 125-145.

EARDLY-WEAVER, Sarah. (2010). "Opening Doors to Opera: the Strategies, Challenges and General Role of the Translator." InTralinea Vol. 12. Electronic version: <http://www.intralinea.org/archive/article/Opening_doors_to_opera_>

EugENI, Carlo. (2006). "Il sopratitolaggio. Definizione e differenze con il sottotitolaggio." Intralinea, Vol. 8. Electronic version: <http://www.intralinea.org/ archive/article/il_sopratitolaggio> 
GreCO, Gian Maria. (2016) "On Accessibility as a Human Right, with an Application to Media Accessibility." In: Matamala, Anna \& Pilar Orero (eds.) 2016. Researching Audio Description. London: Palgrave Macmillan, pp. 11-33. GrIESEL, Yves. (2009) "Surtitling: Surtitles another hybrid on a hybrid stage." TRANS 13, pp. 119-127.

GRIESEL, Yves. (2005) "Surtitles and translation towards an integrative view of theater translation." MuTra 2005 Challenges of Multidimensional Translation: Conference Proceedings, pp. 1-14. Electronic version: <http://euroconferences. info/proceedings/2005_Proceedings/2005_Griesel_Yvonne.pdf>

Gorlée, Dinda L. (2005) Song and Significance: Virtues and Vices on Vocal Translation, Amsterdam \& New York: Rodopi.

HuGHES, Sally; Kathryn Warren-Norton; Pat Spadafora \& Lia E. Tsotsos. (2017) "Supporting Optimal Aging through the Innovative Use of Virtual Reality Technology." Multimodal Technologies Interact 4:23, pp. 2-7.

HUYGELIER, Hanne; Brenda Schraepen; Raymond van Ee; Vero Vanden; Abeele \& Céline R. Gillebert. (2019) "Acceptance of immersive head-mounted virtual reality in older adults." Scientific Reports 9. Electronic version: <https://www. nature.com/articles/s41598-019-41200-6.pdf>

INCLUSION EUROPE. (2016) "Information for all. European standards for making information easy to read and understand." Electronic version: <https://easyto-read.eu/european-standards/>

KAINDL, Klaus. (1997) "Die Übersetzung als Inszenierung: Ein interdisziplinärer Rahmen zur Analyse von Opernübersetzungen.” Target 9:2, pp. 271-287.

Low, Peter. (2017) Translating Song: Lyrics and Texts. London: Routledge.

Low, Peter. (2002) "Surtitles for opera. A specialised translating task". Babel 48:2, pp. 97-110.

Matamala, Anna \& Pilar Orero. (2008) "Opera Translation: An Annotated Bibliography." Translator 14:2, pp. 427-451.

Matamala, Anna \& Pilar Orero. (2007) "Accessible Opera: Overcoming Linguistic and Sensorial Barriers." Perspectives 15:4, pp. 262-278.

MATEO, Marta. (2007a) "Surtitling nowadays: new uses, attitudes and developments." Linguistica Antverpiensia, New Series 6, pp 135-154.

MATEO, Marta. (2007b) "Reception, text and context in the study of opera surtitles." In: Gambier, Yves; Miriam Shlesinger \& Radegundis Stolze (eds.) 2007. Doubts and directions in translation studies. Amsterdam: John Benjamins, pp. 169-182. 
MATEO, Marta. (2002) "Los sobretítulos de ópera: dimensión técnica, textual, social e ideológica." In: Sanderson, Jan (ed.) 2002. Traductores para todo. Actas de las III Jornadas de doblaje y subtitulación. Alicante: Universidad de Alicante, pp. 51-73.

MATEO, Marta. (2001) "Performing musical texts in a target language: The case of Spain." Across Languages and Cultures 2:1, pp. 31-50.

MEle-SCORCiA, Antonia. (2018) "Surtitling and the audience: A love-hate relationship." Jostrans 30. Electronic version: <https://www.jostrans.org/issue30/ art_mele.pdf>

Neves, Josélia. (2010) "Music to my Eyes... Conveying Music in Subtitling for the Deaf and the Hard of Hearing." In: Bogucki, Lukasz \& Krzysztof Kredens (eds.) 2010. Perspectives on Audiovisual Translation, Lodz Studies in Language. Frankfurt am Main: Peter Lang, pp. 123-146.

OnCINS, Estella. (2015) "The tyranny of the tool: surtitling live performances." Perspectives: Studies in Translatology 23:1, pp. 42-61.

Oncins, Estella. (2014). Accessibility for the scenic arts. Ph.D Thesis. Universitat Autònoma de Barcelona. Electronic version: <https://www.tdx.cat/ handle/10803/133314>

REDZIOCH-KorKuZ, Anna. (2018) "Constraints on Opera Surtitling: Hindrance or Help?" Meta 63:1, pp 216-234.

Redzioch-KorkuZ, Anna. (2015) "Media Accessibility and opera in Poland." In: Bogucki, Lukasz \& Mikolaj Deckert (eds.) 2015. Accessing Audiovisual Translation. Frankfurt am Main: Peter Lang, pp. 149-162.

RoberTs, Amy R.; Bob De Schutter, Kelley Franks \& M. Elise Radina. (2018) "Older Adults' Experiences with Audiovisual Virtual Reality: Perceived Usefulness and Other Factors Influencing Technology Acceptance". Clinical Gerontologist 42:1, 27-33, DOI: 0.1080/07317115.2018.1442380.

ROMERO-FresCO, Pablo. (2018). In support of a wide notion of media accessibility: Access to content and access to creation. Journal of Audiovisual Translation, 1(1), 187-204.

SCHÖNE, Benjamin; Marlene Wessels \& Thomas Gruber. (2017) "Experiences in Virtual Reality: a Window to Autobiographical Memory." Current Psychology Research 106:3, pp. 1-5.

SECARA, Alina. (2018) "Surtitling and Captioning for Theatre and Opera." In: Pérez González, Luis (ed.) 2018. The Routledge Handbook of Audiovisual Translation, New York: Routledge, pp. 130-144. 
SilveIRA, Jason M. \& Frank M. Diaz. (2012) "The effect of subtitles on listeners' perceptions of expressivity." Psychology of Music 42:2, pp. 233-250.

SNELl-Hornby, Mary. (2007) "Theatre and Opera Translation." In: Kuhiwczak, Piotr \& Karin Littau (eds.) 2007. A companion to translation studies, Multilingual Matters. Clevedon: United Kingdom, pp. 106-119.

UN. (2015a) "World Population Ageing 2015: Highlights". Electronic version: $<$ https://www.un.org/en/development/desa/population/publications/pdf/ ageing/WPA2015_Highlights.pdf>

UN. (2015b) "Ageing and disability." Electronic version: <https://www.un.org/ development/desa/disabilities/disability-and-ageing.html>

VerveCKen, Anika. (2012) "Surtitles: Types and functions." In: Silvia Bruti \& Elena Di Giovanni (eds) 2012. Audiovisual translation across Europe. An ever-changing landscape. New Trends in Translation Studies Vol. 7. Berlin: Peter Lang.

VirkKUnEN, Rita. (2004) "The source text of opera surtitles." Meta 49:1, pp. 89-97.

W3C WORLD WIDE WEB CONSORTIUM. (2018) "Older Users and Web Accessibility: Meeting the Needs of Ageing Web Users." Electronic version: <https://www.w3.org/WAI/older-users/\#background>

\section{NOTA BIOGRÁFICA / BIONOTE}

Dr. EsTELLA ONCINS is a Senior Researcher at TransMedia Catalonia (Universitat Autònoma de Barcelona, Spain). She holds a PhD in "Accessibility for the Scenic Arts" from the Universitat Autònoma de Barcelona. She has a large experience in providing accessibility for live events as a freelance translator, subtitler, surtitler, respeaker for different Spanish televisions and conferences, and as an audiodescriber for Gran Teatre del Liceu. Her research areas are audiovisual translation, media accessibility and creative industry. She is currently involved in the EU H2020 HELIOS project, being part of the team leading a WP. She is also the Quality Manager and part of the team in charge of IO4 of the ERAMUS+ KA2 EU co-funded project Live Text Access, which aims to create certified learning materials for real-time intralingual subtitlers by respeaking and velotyping. 
Dra. Estella Oncins es investigadora senior de TransMedia Catalonia (Universitat Autònoma de Barcelona, España). Es doctora en "Accesibilidad para las artes escénicas" por la Universitat Autònoma de Barcelona. Cuenta con una amplia experiencia en la provisión de accesibilidad para eventos en vivo como traductora, subtituladora y rehabladora freelance para diferentes televisiones y conferencias. También tiene experiencia como audiodescriptora para el Gran Teatre del Liceu. Sus áreas de investigación son la traducción audiovisual, la accesibilidad en los medios y la industria creativa. Actualmente participa en el proyecto EU H2020 HELIOS, como parte del equipo de la UAB que lidera un WP. También es la Directora de calidad y parte del equipo a cargo del IO4 del proyecto Live Text Access, cofinanciado por ERAMUS + KA2 EU, que tiene como objetivo crear materiales de aprendizaje certificados para subtituladores intralinguales en directo mediante rehablado y velotipia.

Dr. MARIO MONTAGUD is a Senior Researcher at i2CAT Foundation (Barcelona, Spain) and a Part-Time Professor at the University of Valencia (Spain). He holds a PhD in Telecommunications (Cum Laude Distinction) at the Polytechnic University of Valencia (UPV, Spain). His topics of interest include Computer Networks, Interactive and Immersive Media, Synchronization and QoE (Quality of Experience). He is (co-) author of over 70 scientific and teaching publications and has contributed to standardization within the IETF (Internet Engineering Task Force). He is a member of the Editorial Board of international journals and has been a member of the Organization Committee of the many international workshops and conferences. He is also lead editor of "MediaSync: Handbook on Multimedia Synchronization" (Springer, 2018) and Communication Ambassador of ACM SIGCHI (Special Interest Group in Human-Computer Interaction). He is currently involved in three EU H2020 projects, being WP leader in two of them: VR-Together, ImAc and 5G-Picture.

Dr. MARIO MONTAGUD es investigador senior en la Fundación i2CAT (Barcelona, España) y profesor a tiempo parcial en la Universidad de Valencia (España). Es doctor en Telecomunicaciones (Distinción Cum Laude) Universidad Politécnica de Valencia (UPV, España). Sus temas de interés incluyen redes informáticas, medios interactivos e inmersivos, sincronización y QoE (calidad de experiencia). Es (co) autor de más de 70 publicaciones científicas y de enseñanza, y ha contribuido a la estandarización dentro del IETF (Fuerza 
de Trabajo de Ingeniería de Internet). Es miembro del Consejo Editorial de revistas internacionales y ha sido miembro del Comité de Organización de los numerosos talleres y conferencias internacionales. También es editor principal de "MediaSync: Handbook on Multimedia Synchronization" (Springer, 2018) y Embajador de comunicaciones de ACM SIGCHI (Special Interest Group in Human-Computer Interaction). Actualmente está involucrado en tres proyectos europeos H2020, siendo líder de WP en dos de ellos: VR-Together, ImAc y 5G-Picture.

Rocío Bernabé CARO MA in Translation (UGR), MA in Accessible Documents, Technologies and Applications (UNIR) and PhD student in easy-to-understand media services at the Universitat Autònoma de Barcelona. She is also an external collaborator of the research group TransMedia Catalonia. She is Deputy Head of the Professional College of Translation and Interpreting of the SDI in Munich (Germany). She is the project leader of the EU co-funded project Live Text Access that aims to create certified learning materials for real-time intralingual subtitlers by respeaking and velo-typing. She is project partner, accessibility manager and leader of the Intellectual Output 2 of the EU co-funded project EASIT, Easy Access for Social Inclusion Training. She is at the second year of her doctoral research in the field of easy-to-understand audiovisual modalities with a focus on subtitling.

Rocío Bernabé CARo Máster en Traducción (UGR), Máster en Documentos, Tecnologías y Aplicaciones Accesibles (UNIR) y estudiante de doctorado en medios in easy-to-understand en la Universitat Autònoma de Barcelona. También es colaboradora externa del grupo de investigación TransMedia Catalonia. Es directora adjunta de la Escuela Profesional de Traducción e Interpretación de la SDI en Múnich (Alemania). Es líder del proyecto ERASMUS+KA2 cofinanciado por la Unión Europea, Live Text Access, que tiene como objetivo crear materiales de aprendizaje certificados para subtituladores intralinguales en directo mediante rehablado y velotipia. Es miembro, responsable de accesibilidad y líder del IO 2 del proyecto ERASMUS+KA2 EASIT, Easy Access for Social Inclusion Training. Se encuentra en el segundo año de su investigación doctoral en el campo de las modalidades audiovisuales easy-to-understand enfocado en el subtitulado. 
VERÓNICA ARNÁIZ UZQUIZA BA in Translation and Interpreting from the University of Valladolid (UVA), Spain, and MA in Specialised Translation from the UVA and in Audiovisual Translation from the Universitat Autònoma de Barcelona (UAB). She is cu- rrently employed as a lecturer in Translation, Subtitling and Subtitling for the Deaf and the Hard-of-Hearing (UVA). She has also collaborated with the Master in Professional and Institutional Translation (UVA) and the European Master in Audiovisual Translation (UAB). She has published several articles and reviews in different journals and volumes, and has presented a number of papers at international conferences dealing with Translation and Accessibility.

VERÓNICA ARNÁIZ UZQUIZA Diplômée en Traduction et Interprétation à l'Université de Valladolid (UVA), Master en Traduction de Langages d"especialité (UVA) et en Traduction Audiovisuelle à l'Universitat Autònoma de Barcelona (UAB). Professeur à l'UVA, responsable des cours de Traduction, sous-titrage et sous-titrage pour les sourds et malentendants. Enseignante aussi dans le Master en Traduction Professionnelle et Institutionnelle (UVA) et le Master Européen en Traduction Audiovisuelle (UAB). Elle a publié plusieurs articles et participé à de nombreuses conférences internationales sur Traduction et Accessibilité. 